\title{
A Job Satisfaction of Emotional Intelligence, Leadership, Employee Performance with Information Technology
}

\author{
Zairina Ibrahim, Normy Rafida Abdul Rahman, Md Gapar Md Johar
}

\begin{abstract}
To the business overall, the discoveries and consequences of the investigation will give an increasingly solid top to bottom comprehension of the elements that influence worker fulfillment and to help shape the future strategy definition of the business, in this way encouraging tremendously the accomplishments of the destinations of the Malaysian government in upgrading the unwavering quality and proficiency of the arrangement of the administrations of information will help observing the association accomplishment towards the thousand years objectives just as vision 2020 targets. Job satisfaction make sure that the right employees are recruited and retained in an organization. It also maintains productivity by keeping the workforce constantly engaged and motivated. It has also been proven that job satisfaction controls the ill effects of role problems and job induced stress, besides decreases labor turnover for better employees.
\end{abstract}

Index Terms: Emotional Intelligence; Leadership, Employee Performance; Information Technology; Job Satisfaction.

\section{INTRODUCTION}

A job satisfaction is progressively getting to be vital in the working environment. Bosses presently perceive that the more joyful their representatives are, the better will be their mentalities towards the work, the higher their inspiration and the better will be their execution. A job satisfaction in any field of work depends a ton on how helpful the workplace is. The work itself, the compensation and the degree for advancement are just a portion of the components which affect job satisfaction. Job satisfaction is ordinarily characterized as a representative's full of feeling responses to an occupation dependent on an examination of wanted results and genuine results (Jonghak, 2017).

The educator activity satisfaction is essential as it directly affects understudies' accomplishment and their future profession. An instructor who is unsatisfied with his or her activity will in general be unmotivated and bound to escape from his or her duties. In these conditions, we will in general observe an expansion in truancy among educators. In fact, an instructors normally show little worry in institutions matters and this clearly negatively affects the execution of our youngsters. Different investigations have been completed in the past to evaluate the effect of inspiration and job satisfaction on worker efficiency and execution. A portion of these examinations have discovered a positive connection between job satisfaction and occupation execution which prompts

Revised Manuscript Received on July 1, 2019.

Zairina Ibrahim, Information Technology and Innovation Centre, Management and Science University, University Drive Seksyen 13, Shah Alam 40100, Malaysia.

Md Gapar Md Johar, Information Technology and Innovation Centre, Management and Science University, University Drive Seksyen 13, Shah Alam 40100, Malaysia.

Normy Rafida Abdul Rahman, Faculty Business Management and Professional Studies, Management and Science University, University Drive Seksyen 13, Shah Alam 40100, Malaysia. the end that fulfilled workers will in general perform much superior to less fulfilled ones. As a whole, job satisfaction shows much individuals like their employments. There are vital reasons why we ought to be worried about employment satisfaction (Spector, 1997).

A job satisfaction is a standout amongst the most explored subjects in the fields of hierarchical conduct. The most utilized research meaning of job satisfaction and also it is characterized as a pleasurable or positive passionate state coming about because of the examination of one's activity or professional adventures. It is presently perceived that activity fulfillment is a worldwide idea that additionally contains different features including pay, advancements, associates, supervision, the work itself, acknowledgment, working conditions, and friends and the executives. A standout amongst the most vital is that activity satisfaction can prompt worker practices that influence hierarchical working and execution (Rowden, 2002).

An employment fulfillment has additionally been characterized as the degree to which a staff part has good or positive emotions about work or the workplace. It alludes to the uplifting mentalities or enthusiastic demeanors individuals may pick up from work or through parts of work and it is characterized job satisfaction as the inclination and view of a specialist with respect to his or her work and how the person feels himself well in an association. The situational way to deal with job satisfaction (Hackman and Oldman, 1980) comprehends it to be chiefly impacted by working and hierarchical conditions (Herzberg, 1966). It is depict job satisfaction as a lot of positive or troublesome affections for the representatives to see their work and that decide the likelihood of a noteworthy mien to accomplish higher execution. Along these lines, job satisfaction alludes to a person's general disposition toward his or her activity.

Therefore, job dissatisfaction alludes to miserable or negative emotions about work or the workplace. There exist numerous elements which may result in employment disappointment. However, some of them are poor working conditions, exhaust, low dimensions of pay, no extent of advancement or professional success and absence of acknowledgment. Thus, what is most noticeably awful are the results of job disappointment which clearly influence both the workers and the association. It might result in loss of inspiration, absence of intrigue, disappointment, poor profitability, non-attendance and even high turnover rates. The principal, the feature approach, is utilized to discover what components of the activity produce satisfaction or disappointment. This can be especially valuable for associations that desire to recognize regions of disappointment that they need to improve. The second, the worldwide methodology, is utilized to evaluate generally speaking job satisfaction in connection to different factors of intrigue (Ganzach, 1998). 


\section{A. Problem Statement}

A job satisfaction is expanding in significance, as the challenge for ability is high and as yet developing. It isn't difficult for a contender to rival singular components of work, for example, pay rates and advantages. Moreover, centers on the reasons of automatic turnover, willful turnover, and advancement for representatives to leave a specific organization. Besides, it's stated that the two sorts of turnover are the most crushing for associations. The impact of deliberate turnover incorporates loss of execution, information, skill, relationship, and loss of the time and assets that it took to prepare the worker. This prompts a sentiment of frailty and influences the execution of the workers who are left a direct result of the steady disturbance of administrations and a lot of progress which accordingly influences the general execution of the organization (Bar-On, 1997).

An employee turnover rates have, inside the most recent decade become an across the nation pestilence. Thus, employees of higher reputed organizations never again feel the feeling of organization dedication that once existed. An expanding quantities of corporate mergers and acquisitions have left workers feeling confined from the organizations that they served and frequented by worries of generally speaking professional stability. This has driven the workers to concentrate more on employment chasing instead of execution subsequently harming the general execution of the organization. However, with the issue of expanding employee's turnover in the industry, one marvels if the objective of the government concerning the development and extension of the segment will be figured it out. It hence requires a more prominent move to be made to discover how to hold the organization's profitable workers and the variables liable to influence them to stay in the business to help accomplish organization goals and that of the administration. This examination contemplate looks to explore the elements that may impact representative fulfillment and how these components influence maintenance of employees (Ganzach, 1998).

The present dimension of job satisfaction in their particular working industry. Accordingly, with the steady changes in proprietorship and resultant supervisory crews which dependably accompanies a bunch of better approaches for getting things done. The majority of this new methodologies have not performed well in the market on the grounds that the representatives themselves don't have faith in them and will accordingly not perform ideally to meet this objectives. This has prompted the inauspicious execution of the organization all in all (Ganzach, 1998).

\section{B. Objective}

The purpose of this study is to know and identify the level of satisfaction among the employees. This study is become something very important so that we may be aware of the job satisfaction of the employees. This study will be particularly focuses on the job satisfaction among the employees of an organization.

i. The study is to find out the employees satisfaction level of the organization

ii. To study the relationship between emotional intelligence with information technology of the employees on job satisfaction

iii. To investigate the relationship between leadership with information technology and employee job satisfaction

iv. To examine the relationship between employee performance with information technology and job satisfaction

\section{Research Question}

i. Why emotional intelligence with information technology should be balanced among employees in an organization? ii. How important is leadership with information technology on job satisfaction in an organization?

iii. Do employees performance with information technology changes when it comes to job satisfaction?

\section{LITERATURE REVIEW}

This part will fill in as the establishment for the improvement of the examination. It will talk about the pertinent writing identifying with the elements that influence worker work fulfillment. It will explicitly concentrate on theoretical survey, past examinations regarding the matter with an end goal to feature the relationship of those exploration and this exploration and an audit of a portion of the writing on the factors of the examination. These factors include of ability improvement, compensate, association structure, association duty and impact of administrators on employment fulfillment, these factors structure the premise of the examination. The section additionally gives the examination hole and the applied structure that demonstrates the relationship between the factors of the investigation.

\section{A. Emotional Intelligence with Information Technology on}

\section{Job Satisfaction}

An emotional intelligence is a generally new and developing field of research, basic for some zones, for example, business and the executives. According to Dwindle Salovey and John Mayer (1990), an initially proposed their hypothesis of emotional intelligence in 1990. In fact, over the mediating decades, scholars have created a few meanings of emotional intelligence. In light of an examination of the writing, think about that there are two models of emotional intelligence of mental capacity models and blended models (Zeidner et al., 2004).

Therefore, mental capacity models center around fitness for preparing full of feeling data, in which emotional intelligence is seen as a very much characterized and thoughtfully related arrangement of intellectual capacities for the handling of passionate data and controlling feeling adaptively. According to Salovey and Mayer, 1990, an emotional intelligence is the capacity to screen one's very own and others' feelings, to segregate among them, and to utilize the data to manage one's reasoning and activities. However, by Mayer et al., 1999 \& 2000, the individuals who conceptualize emotional intelligence as a genuinely very much characterized set of feeling preparing aptitudes try to evaluate emotional intelligence with target execution tests, for example, taking care of issues or distinguishing proof of feelings in pictures.

The blended models conceptualize emotional intelligence as a differing develop, including parts of identity just as the capacity to see, acclimatize, comprehend, and oversee feelings. These blended models incorporate persuasive elements and emotional manners (Bar-On, 1997), portrays emotional intelligence as a variety of non-psychological capacities, capabilities, and aptitudes that impact one's capacity to prevail with regards to adapting to natural interest and weights. According to Goleman, 1998 \& 2000, proposes that two area aspects characterize the capabilities related with emotional intelligence of capacity mindfulness versus the executives of feeling and target regardless of whether skill identifies with self-versus others. An emotional intelligence is in this manner portrayed by four segments of mindfulness of feelings, social mindfulness or familiarity with feelings in others, the executives of feelings in self and the board of feelings in others (Goleman, 1998 \& 2000).

An emotional intelligence and job satisfaction are not very many experimental examinations have broke down the connection among emotional intelligence and employment fulfillment. According to Abraham 2000, found that despite the fact that emotional intelligence was identified with occupation fulfillment. This was directed by a natural trademark of work control. The immediate constructive outcome that by Bar-On

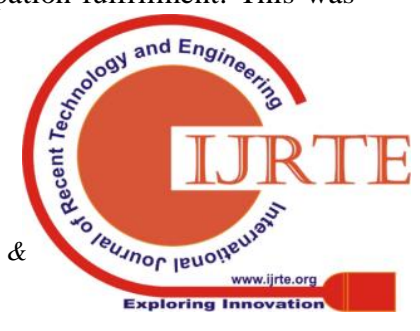


1997, reports may be clarified by the example, which comprised of people in more elevated amount occupations of instructors, medical caretakers, and salespersons, where the natural conditions appease their capacities. In total, when the natural conditions appease the people's capacities, they may have more elevated amounts of fulfillment (Bar-On, 1997).

This elucidation is predictable with the writing recommending that individuals want conditions that fit their attributes (O'Reilly et al., 1991), and with the objective decision writing, which proposes that the decision of objective relies upon capacity (Locke and Latham, 1990). Likewise, Ganzach 1998, presents a model of connections between knowledge, work unpredictability and occupation fulfillment (Ganzach, 1998).

\section{B. Leadership with Information Technology on Job Satisfaction}

Leadership is seen as a vital indicator and assumes a focal job. The leadership is a management work, which is for the most part coordinated towards individuals and social cooperation, just as the procedure of affecting individuals so they will accomplish the objectives of the association (Skansi, 2000). However, various examinations did in a few nations demonstrated that there is a positive connection among's administration and the activity fulfillment of medicinal services suppliers (Seo et al., 2004; Vance and Larson, 2002; Chiok Foong Loke, 2001; Martin, 1990; Dunham-Taylor, 2000; Stordeur et al., 2000; Hespanhol et al., 1999; Lowe et al., 1996; Berson and Linton, 2005; Morrison et al., 1997; Mosadeghrad, 2003a).

Authoritative accomplishment in getting its objectives and destinations relies upon directors and their leadership style. By utilizing suitable leadership styles, chiefs can influence representative job satisfaction, duty and efficiency. Leadership style can be seen as a progression of administrative dispositions, practices, attributes and abilities based on individual and hierarchical qualities, initiative interests and dependability of workers in various circumstances (Mosadeghrad, 2003b). It is the capacity of a pioneer to impact subordinates to performing at their most astounding ability. This factor catches the degree to which the board regards laborers, works with genuineness and uprightness, advances proficiency, and has open lines of correspondence with representatives (Aronson et al., 2003)

The subject of leadership is fascinating for some analysts. The proceeded with look for good pioneers has brought about the improvement of numerous leadership speculations. Studies have been done to decide how leadership practices can be utilized to impact representatives for improved hierarchical results (Kreitner, 1995). In the previous quite a few years, the board specialists have experienced an unrest by the way they characterize leadership and their mentalities toward it. They have gone from an extremely traditional totalitarian way to deal with an exceptionally innovative and participative methodology. Thoughts regarding the board and leadership have changed significantly as of late. Individuals today are better-taught and progressively well-spoken. They can never again be told similarly as previously. There should be considerably more contribution and support at work (Stewart, 1994).

There are a few styles of leadership, for example, imperious, bureaucratic, free enterprise, magnetic, popularity based, participative, situational, value-based, and transformational leadership (Mosadeghrad 2003b \& 2004). Not every person concurs that a specific style of leadership will result in the best type of hierarchical conduct. Diverse styles were required for various circumstances and every pioneer had to realize when to show a specific methodology. Nobody's leadership style is perfect for each circumstance, since a pioneer may have learning and abilities to act viably in one circumstance yet may not develop as adequately in an alternate circumstance (Ganzach, 1998).

\section{Employee Performance with Information Technology on Job Satisfaction}

Execution criteria are guidelines for representative conduct at work. This criterion contains considerably more than how a representative takes every necessary step. Workers are appraised on how well they carry out their responsibilities contrasted and a lot of models controlled by the business. Therefore, situational hypotheses accept that the association of factors, for example, task attributes, authoritative qualities and individual attributes impacts job satisfaction (Hoy and Miskel, 1996). The individual assesses the situational attributes before beginning of work (Quarstein et al., 1992), while situational events are assessed a short time later. As indicated by Quarstein et al., 1992, generally speaking fulfillment is an element of a mix of situational attributes and situational events. The situational qualities normally proposed as key factors in job satisfaction seem to be: the work itself, pay, advancement, supervision and associates, albeit different factors, for example, worker inclusion and hierarchical duty may affect too (Smith et al., 1969).

There have been various examinations into job satisfaction which investigate the effect of statistic attributes, for example, age, sex, residency, and training (Clark, 1993; Clark and Oswald, 1995; Hickson and Oshagbemi, 1999; Oshagbemi, 1998, 2000a \& b). The outcomes propose the presence of connections between statistic qualities and job satisfaction, yet the proof will in general be blended, with positive and negative connections in some cases recognized for the collaborations between same factors (Clark, 1993).

The connection between job satisfaction and performance is as yet open to address; it is indiscreet to expect that high job satisfaction rompts superior, or that superior workers are happy with their employments (Euske et al., 1980). The various investigations demonstrate a frail connection (Petty et al., 1984; Iaffaldano and Muchinsky, 1985) while others (Caldwell and O'Reilly, 1990; Spector, 1997) propose a potential connection among satisfaction and performance. The circumstances and logical results determinants are as yet hazy and it can't be expected that fulfillment prompts superior, or that superior workers are fundamentally happy with their occupations (Euske et al., 1980).

\section{FORMATION OF THE THEORETICAL FRAMEWORK OF THE STUDY}

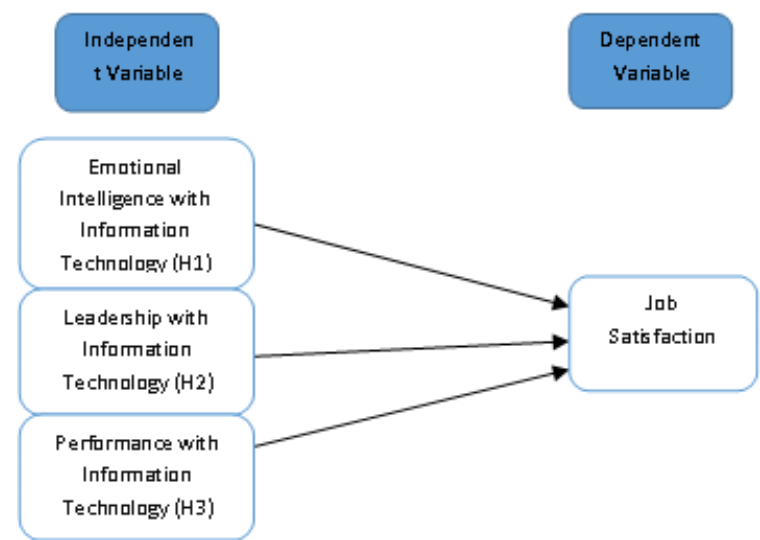

Fig. 1. Hypothesis of the Theoretical Framework of the Study

\section{A. Hypothesis of the Theoretical and Conceptual Framework of the Study}

H1- There is a relationship between emotional intelligence with information technology and job satisfaction 
It follows that research on emotional intelligence should be acutely sensitive to certain factors and unlike conventional ability. An emotional intelligence may have both positive and negative associations with performance, depending on contextual characteristics.

H2- There is a relationship between leadership with information technology and job satisfaction

The results of this research will allow a better understanding of the relationship between leadership with information technology and employee job satisfaction. It is anticipated that a better understanding of these issues and their relationships can aid further research, pinpoint better strategies for recruiting, promotion, and training of future hospital managers and employee.

H3- There is a relationship between performance with information technology and job satisfaction

As for the relationship between performance with information technology and job satisfaction, the results show no significant relationship, this seems to bear out the findings.

\section{METHODOLOGY}

Research methodology can be characterized as a movement that includes discovering, in a pretty much efficient manner, things you didn't have an inkling according to (Walliman and Walliman, 2011). The methodology is the philosophical system inside which the exploration is led or the establishment whereupon the examination is based (Brown, 2006).

The research methodology section of an examination portrays explore strategies, methodologies and structures in detail featuring those utilized all through the investigation, supporting my decision through depicting points of interest and hindrances of each methodology and configuration considering their functional pertinence to our exploration. According to O'Leary, 2004, portrays strategy as the system which is related with a specific arrangement of paradigmatic presumptions that we will use to lead our exploration. By Allan and Randy, 2005, demand that when directing an examination strategy should meet the accompanying two criteria of right off the bat, the technique ought to be the most proper to accomplish goals of the examination. Besides, it should be made conceivable to recreate the system utilized in different inquiries about of a similar sort (O'Leary, 2004).

\section{A. Research Design}

Descriptive research design will be employed to determine the relationship between the dependent and the independent variables and to establish any association between these variables. According to Mugenda \& Mugenda, 2003, descriptive survey design helps a researcher to gather, summarize, present and interpret information for the purpose of clarification. Statistical instrument to be used for the research analysis will mainly be inferential statistics, specifically correlation matrix and multiple regression analysis. The researcher will employ the questionnaire strategy for the study. This strategy is proposed because it allows the collection of a large amount of data from a sizable population in an economical manner. According to Saunders et al., 2009, recommend this strategy because the method allows researchers to collect quantitative data which can be analyzed quantitatively using inferential statistics. The method is also perceived as authoritative by people in general and is both comparatively easy to explain and to understand. (Muchinsky \& Iaffaldano, 1985).

\section{B. Data Collection Methods}

Data accumulation is a procedure of gathering data from all the pertinent sources to discover answers to the exploration issue, test the theory and assess the results. Data accumulation strategies can be partitioned into two classes: optional techniques for information gathering and essential strategies for information gathering (Walliman, 2011).

\section{Secondary Data Collection Methods}

Secondary information is a sort of information that has just been distributed in books, papers, magazines, diaries, online entrances and so on. There is a bounty of information accessible in these sources about your exploration territory in business considers, practically paying little mind to the idea of the examination region. Consequently, utilization of suitable arrangement of criteria to choose optional information to be utilized in the investigation assumes a significant job regarding expanding the dimensions of research legitimacy and dependability. These criteria incorporate, yet not constrained to date of distribution, certification of the creator, dependability of the source, nature of dialogs, profundity of examinations, the degree of commitment of the content to the improvement of the exploration territory and so on ( Muchinsky \& Iaffaldano, 1985).

\section{Primary Data Collection Methods}

Primary information gathering techniques can be separated into two gatherings: quantitative and subjective. Quantitative information accumulation strategies are situated in numerical counts in different configurations. Techniques for quantitative information gathering and investigation incorporate polls with shut finished inquiries, strategies for connection and relapse, mean, mode and middle and others. Quantitative techniques are less expensive to apply and they can be connected inside shorter term of time contrasted with subjective strategies. In addition, because of an abnormal state of institutionalization of quantitative techniques, it is anything but difficult to make correlations of discoveries (Smith et al., 1969).

The qualitative research strategies, in actuality, don't include numbers or numerical computations. Qualitative research is intently connected with words, sounds, feeling, feelings, hues and different components that are non-quantifiable. The qualitative examinations plan to guarantee more prominent dimension of profundity of understanding and subjective information accumulation techniques incorporate meetings, surveys with open-finished inquiries, center gatherings, perception, amusement or pretending, contextual analyses and so forth. Your decision between quantitative or qualitative techniques for information accumulation relies upon the territory of your examination and the idea of research points and destinations (Smith et al., 1969).

The researchers may choose themselves on what type of technique they want use for their research either quantitative or qualitative technique for data collection for their research. It is depended on the situation and area where they can use which technique either qualitative or quantitative and for their goals and objectives of their research. The distributed questionnaire to several and students to fill in the form of our research, in order to know their experience and knowledge in this process. Therefore, focused on degree students, whereas could get specific answers from them because each and every degree student have been to internship program before going to degree. They have experience the job satisfaction. A prepared 400 questionnaires to several and students to manage to get enough responds which is from the primary data from the faculty. The secondary data where they get the information is from articles and journals.

\section{E. Sampling}

Sampling is the process from a population of interested by studying the sample may fairly generalize our results. The discussion of major distinction between probability and Non probability sampling methods and work through the major types in each. Through the survey, the researcher made about 15000 students are

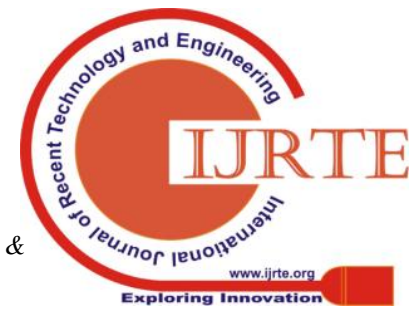


studying, there are 3600 of degree students (Shukri, A. Y., 2019). In fact, 400 students who are active in their studies and academic achievements.

\begin{tabular}{|c|c|c|} 
Table I: Sampling of population \\
\hline Population & Sample size & $\begin{array}{c}\text { Number of degree } \\
\text { students }\end{array}$ \\
\hline 15000 & 400 & 3600 \\
\hline
\end{tabular}

\section{DISCUSSION AND RESULT}

\section{A. Discussion and Conclusion}

The 550 questionnaires distributed, 400 (usable) were returned, a response rate of 55 per cent. The internal reliability of the items was tested using Cronbach's alpha, with scores of 0.95 for satisfaction and 0.85 for self-performance being generated Table 3 . The results show that respondents were most satisfied with co-workers $(\mathrm{M}=2.26)$ and quality of supervision $(\mathrm{M}=2.25)$, but less satisfied with the work itself $(\mathrm{M}=1.81)$, promotion $(\mathrm{M}=1.45)$ and pay $(\mathrm{M}=1.07)$. The overall job satisfaction score was $(\mathrm{M}=1.78)$. The relationship between all the facets was found to be significant, indicating the respondents' job satisfaction is not related to an individual facet.

The data were also subjected to a non-parametric Friedman test. The mean ranks for each facet were co-workers, $M R=3.98$; supervision, $\mathrm{MR}=3.96$; work itself, $\mathrm{MR}=2.95$; promotion, $\mathrm{MR}=2.42$; and pay, $\mathrm{MR}=1.72$. The significance (sig. 0.0001 ) at the 0.05 level suggests the satisfaction was not independent in the individual job facets. As far as the relationship between job satisfaction and socio-demographic characteristics; the results of a one-way ANOVA indicate that overall job satisfaction is slightly related to the age of the employee, but is not statistically significant at the 0.05 level $(\mathrm{p}=0.59)$. When the individual job satisfaction facets and age, the mean job satisfaction score in each facet was plotted against the different age groups, the results indicate a weak relationship between age and facets of job satisfaction.

The results show little variation between overall job satisfaction and respondents' tenure, but that overall job satisfaction level is lowest for workers with 11to 20years tenure and it slightly increases thereafter. The results of a one-way ANOVA show that overall job satisfaction is slightly related to tenure, but not statistically significant at the 0.05 level $(p=0.24)$. Further analysis indicates that respondents with less than five year's tenure are highly satisfied with co-workers and supervision followed by the work itself. Those with less than five years are least satisfied with pay and promotion. As the two gender groups were not normally distributed, a Mann-Whitney U test was performed to test the relationship between gender and job satisfaction with each facet. Respondents with a school certificate reported the lowest levels of overall job satisfaction and the highest job satisfaction levels were reported from those with a college certificate. While the results indicate some differences in satisfaction with the different facets these are not statistically significant

Table II: The main characteristics of the sample

\begin{tabular}{|l|l|l|}
\hline $\begin{array}{l}\text { Characteristi } \\
\text { c }\end{array}$ & $\begin{array}{l}\text { Frequenc } \\
\text { y }\end{array}$ & $\begin{array}{l}\text { Percentage } \\
\text { (\%) }\end{array}$ \\
\hline Gender & & \\
\hline $\begin{array}{l}\text { Female } \\
\text { Male }\end{array}$ & 255 & 63.75 \\
\cline { 2 - 3 } $\begin{array}{l}\text { Education } \\
\text { PhD } \\
\text { Master } \\
\text { Degree } \\
\text { Bachelor } \\
\text { Degree }\end{array}$ & 145 & 36.25 \\
\cline { 2 - 3 } & 28 & 7 \\
\cline { 2 - 3 } & 45 & 11.25 \\
\cline { 2 - 3 } & 198 & 49.5 \\
\cline { 2 - 3 } & 43 & 15.25 \\
\hline
\end{tabular}

\begin{tabular}{|l|l|l|}
\hline $\begin{array}{l}\text { Diploma } \\
\text { Certificate } \\
\text { School } \\
\text { Certificate }\end{array}$ & 25 & 6.25 \\
\hline $\begin{array}{l}\text { Age } \\
<25 \\
25-34 \\
35-44 \\
>44\end{array}$ & 89 & 22.25 \\
\cline { 2 - 3 } & 98 & 24.5 \\
\hline & 152 & 38 \\
\cline { 2 - 3 } $\begin{array}{l}\text { Length } \\
\text { service }\end{array}$ & 61 & 15.25 \\
\hline $0-5$ & 223 & \\
\hline $6-10$ & 86 & 22.25 \\
\hline $11-20$ & 61 & 15.25 \\
\hline$>21$ & 30 & 7.5 \\
\hline Note: $\mathbf{N}=\mathbf{4 0 0}$ & & \\
\hline
\end{tabular}

Table III: Internal reliability of the job satisfaction facets

\begin{tabular}{|l|l|}
\hline Subscale & Coefficient alpha \\
\hline Work & 0.80 \\
\hline Pay & 0.71 \\
\hline Promotion & 0.95 \\
\hline Supervision & 0.91 \\
\hline Co-workers & 0.85 \\
\hline
\end{tabular}

The third area of investigation was the relationship between job satisfaction and job performance. The self-reported scores for each of the four measures were on the higher side of the seven-point scale. The highest score was for productivity $(\mathrm{M}=4.64)$, followed jointly by own performance compared to colleagues and quality of own performance $(\mathrm{M}=4.61)$. The respondents' rating of their colleagues' performance attracted the lowest score $(\mathrm{M}=4.18)$. The overall performance mean was 4.52 .

However, these results may be skewed by the self-evaluation method with self-ratings are being inflated and colleagues performance under-rated. Further analysis of the data revealed that self-reported performance is related to age; in each of the four performance measures, and overall, the score was higher in the 25-34 group than in the , 25 years. The score was lower in the 35 44 years group and considerably higher in the 44 years group. As far as the relationship between tenure and mean job performance is concerned, the results show that self-reported performance increases linearly with tenure; the only exception being the respondents own performance rating which increases linearly up to the 11-20 years group then declines for the . 21 years group. The self-reported performance of males is higher in all facets of job performance than that of females. The results of the Spearman rank order correlation test indicate there is no significant relationship between job satisfaction and job performance $(\mathrm{r}=20.02, \mathrm{p}=0.91)$.

\section{B. Result of Hypotheses Testing}

H1: There is a relationship between emotional intelligence with information technology and job satisfaction

Conclusion: Significance relationship between emotional with information technology and job satisfaction is satisfaction of indicated 0.001 with p-values 0.05 . Therefore, coefficient job satisfaction is $0.95 \%$ is significantly.

H2: There is a relationship between leadership with information technology and job satisfaction 
Conclusion: Significance relationship between leadership with information technology and job satisfaction of indicated 0.05 with p-values 0.59 . Therefore, coefficient job satisfaction is $0.95 \%$ is significantly.

H3: There is a relationship between performance with information technology and job satisfaction

Conclusion: Significance relationship between performance with information technology and job satisfaction of indicated 0.05 with p-values 0.24 . Therefore, coefficient job satisfaction is $0.95 \%$ is significantly.

\section{CONCLUSION}

A work environment is made up of a range of factors, including company culture, management styles, hierarchies, technology and human resources policies. Employee satisfaction is the degree to which employees feel personally fulfilled and content in their job roles. Employee turnover is the rate at which employees leave their employers, whether voluntarily or involuntarily. These three distinct concepts are inseparably linked; workplace environments greatly influence employee satisfaction, which in turn directly affects employee turnover rates. Knowing how to use a positive work environment to increase employee satisfaction and reduce turnover is a key to developing a high- performance workforce.

However, all organisations, including those in the public or private sector, should guide their institutions toward development of a strong commitment to organisational values that enhance organisational performance. Thus, tax administrators should determine their existing cultural values and tax employees' attitudes to find ways for improving tax administration efficiency and effectiveness. Without doubt, cultural and attitude change is a difficult process but can be implemented with planned programs and actions that can create a culture which reduces employee stress and generates employee with information technology on job satisfaction.

\section{REFERENCES}

1. Abraham, R. 2000. The Role of Job Control as a Moderator of Emotional Dissonance and Emotional Intelligence - Outcome Relationships. The Journal of Psychology. 134(2), 169 - 184.

2. Allan, A. J. \& Randy, L. J. 2005. Writing the Winning Thesis or Dissertation. A Step-by-Step Guide, Corwin Press, California.

3. Aronson, K. R., Sieveking, N., Laurenceau, J. P. and Bellet, W. 2003. Job satisfaction of psychiatric hospital employees: a new measure of an old concern. Adm. Policy Ment. Health. 30(5), pp. 437 - 52.

4. Bar-On, R. (1997a). The Emotional Quotient Inventory (EQ-i): A test of emotional

5. Bar-On, R. (1997a). The Emotional Quotient Inventory (EQ-i): A test of emotional

6. Bar-On, R. (1997a). The Emotional Quotient Inventory (EQ-i): A test of emotional

7. Bar-On, R. (1997a). The Emotional Quotient Inventory (EQ-i): A test of emotional

8. Bar-On, R. (1997a). The Emotional Quotient Inventory (EQ-i): A test of emotional

9. Bar-On, R. (1997a). The Emotional Quotient Inventory (EQ-i): A test of emotional

10. Bar-On, R. (1997a). The Emotional Quotient Inventory (EQ-i): A test of emotional

11. Bar-On, R. (1997a). The Emotional Quotient Inventory (EQ-i): A test of emotional

12. Bar-On, R. (1997b). The Emotional Quotient Inventory (EQ-i): Technical manual.

13. Bar-On, R. (1997b). The Emotional Quotient Inventory (EQ-i): Technical manual.

14. Bar-On, R. (1997b). The Emotional Quotient Inventory (EQ-i): Technical manual.

15. Bar-On, R. (1997b). The Emotional Quotient Inventory (EQ-i): Technical manual.

16. Bar-On, R. (1997b). The Emotional Quotient Inventory (EQ-i): Technical manual.
17. Bar-On, R. (1997b). The Emotional Quotient Inventory (EQ-i): Technical manual.

18. Bar-On, R. (1997b). The Emotional Quotient Inventory (EQ-i): Technical manual.

19. Bar-On, R. (1997b). The Emotional Quotient Inventory (EQ-i): Technical manual.

20. Bar-On, R. 1997a. The Emotional Quotient Inventory (EQ-i): A test of emotional intelligence. Toronto, Canada: Multi-Health Systems, Inc.

21. Bar-On, R. 1997b. The Emotional Quotient Inventory (EQ-i): Technical manual. Toronto, Canada: Multi-Health Systems, Inc.

22. Berson, Y. and Linton, J. D. 2005. An examination of the relationships between leadership style, quality, and employee satisfaction in R\&D versus administrative environments. $R \& D$ Management. 35 , pp. $51-60$

23. Brown, R. B. 2006. Doing Your Dissertation in Business and Management: The Reality of Research and Writing, Sage Publications

24. Caldwell, D. F. \& O'Reilly, C. A. 1990. Measuring person-job fit with a profile-comparison process. Journal of Applied Psychology. 75(6), 648 $-657$.

25. Causes, and Consequences. California: SAGE Publications,

26. Chiok Foong Loke, J. 2001. Leadership behaviours: effects on job satisfaction, productivity and organizational commitment. Journal of Nursing Management. 9(4), pp. 191 - 204.

27. Chiva, R. \& Alegre, J. 2007. Emotional International and Job Satisfaction the Role of Organizational Learning Capability. Emerald Group Publishing Limited.

28. Clark, A. \& Oswald, A. 1995. Satisfaction and comparison of Income.

29. Clark, A. 1993. Job satisfaction and Gender: Why are women so happy at work, ESRC Research Centre on micro - social change? University of Essex, London.

30. Cohen, L., Manion, L., Morrison, K. \& Morrison, R.B. 2007. Research Methods in Education, Routledge.

31. Cranny, C. J., Smith, P. C., \& Stone, E. F. 1992. Job Satisfaction: How People Feel about their Jobs and How it Affects their Performance. Lexington Books: New York.

32. Crossman, A. \& Abou-Zaki, B. 2003. Job satisfaction and employee performance of Lebanese banking staff. Journal of Managerial Psychology, Vol. 18(4), pp. 368-376.

33. Dunham-Taylor, J. 2000. Nurse executive transformational leadership found in participative organizations. Journal of Nursing Administration. 30(5), pp. 241 - 50.

34. Euske, K. J., Jackson, D. W. \& Reif, W. E. 1980. Performance and satisfaction of bank managers. Journal of Bank Research. 11(1), pp.36 42.

35. Ganzach, Y. 1998. Intelligence and job satisfaction. Academy of Management Journal, 41, 526 - 539

36. Goleman, D. 1998a. Working with emotional intelligence. New York: Bantam Books.

37. Goleman, D. 1998b. What makes a leader? Harvard Business Review, November - December.

38. Goleman, D. 2000b. Leadership that gets results. Harvard Business Review. March - April.

39. Hackman J.R. \& Oldham G.R. (1980). Work Redesign.

40. Hackman J.R. \& Oldham G.R. (1980). Work Redesign.

41. Hackman, J. R. \& Oldham, G. R. 1980. Work Redesign. Philippines:Addison-Wesley.

42. Herzberg, F. 1966. Work and the nature of man. Cleveland: World Publishing Company.

43. Hespanhol, A., Pereira, A. C. and Pinto, A. S. 1999. Job satisfaction in Portuguese physicians in general medicine. Aten Primaria. 24, pp. 456 61.

44. Hickson, C. \& Oshagbimi, T. 1999. The effect of age on the satisfaction of academics with teaching and research. International Journal of Social Economics. 26(4) pp. 537 - 544.

45. Hoy, W. K., \& Miskel, C. G. 1996. Educational administration: Theory, research, and practice. New York: McGraw-Hill.

46. Iaffaldano, M. T., \& Muchinsky, E. M. 1985. Job satisfaction and job performance: A meta-analysis. Psychological Bulletin. 97, 251 - 273.

47. intelligence. Toronto, Canada: Multi-Health Systems, Inc.

48. intelligence. Toronto, Canada: Multi-Health Systems, Inc.

49. intelligence. Toronto, Canada: Multi-Health Systems, Inc.

50. intelligence. Toronto, Canada: Multi-Health Systems, Inc.

51. intelligence. Toronto, Canada: Multi-Health Systems, Inc.

52. intelligence. Toronto, Canada: Multi-Health Systems, Inc.

53. intelligence. Toronto, Canada: Multi-Health Systems, Inc.

54. intelligence. Toronto, Canada: Multi-Health Systems, Inc. 
55. Jonghak, S. 2017. The effect of information technology on IT-facilitated coordination, IT-facilitated autonomy, and decision-makings at the individual level. Applied Economics 49(2), pp. 138 - 155.

56. Kreitner, R. 1995. Management. 6th ed. Houghton Mifflin, Boston, MA.

57. Ling-Hsing Chang, C., Chen, V., Klein, G. \& Jiang, J. J. 2011. Information system personnel career anchor changes leading to career changes. European Journal of Information Systems. 20(1), pp 103 117.

58. Locke, E. A., \& Latham, G. P. 1990a. A theory of goal setting and task performance. Englewood Cliffs, NJ: PrenticeHall.

59. Locke, E. A., \& Latham, G. P. 1990b. Work motivation and satisfaction: Light at the end of the tunnel. Psychological Science. 4, 240 - 246.

60. Lowe, K. B., Kroeck, K. G. and Sivasubramaniam, N. 1996. Effectiveness correlates of transformational and transactional leadership: a meta-analytic review. The Leadership Quarterly. 7, pp. 385 - 425.

61. Martin, B. J. 1990. A successful approach to absenteeism. Nursing Management. 21, pp. 45 - 8.

62. Mayer, J. D., \& Cobb, C. D. 2000. Educational policy on emotional intelligence: Does it make sense? Educational Psychology Review. 12, $163-183$.

63. Mayer, J. D., DiPaolo, M. T., \& Salovey, P.1990. Perceiving affective content in ambiguous visual stimuli: A component of emotional intelligence. Journal of Personality Assessment, 54, 772-781.

64. McMurtrey, M. E., Zeltmann, S. M., Downey, J. P. \& McGaughey, R. E. 2011. Seniors and Technology: Results from a Field Study. Journal of Computer Information Systems. 51(4), pp 22 - 30.

65. Morrison, R. S., Jones, L. and Fuller, B. 1997. The relation between leadership style and empowerment on job satisfaction of nurses. Journal of Nursing Administration. 27(5), pp. 27 - 34.

66. Mosadegh Rad, A. M. \& Yarmohammadian, M. H. 2006. A study of relationship between managers' leadership style and employees' job satisfaction. International journal of health care quality assurance incorporating Leadership in health services, 19(2), pp. 11-28.

67. Mosadeghrad, A. M. 2003a. The role of participative management (suggestion system) in hospital effectiveness and efficiency. Research in Medical Sciences. 8(3), pp. 85 - 9.

68. Mosadeghrad, A. M. 2003b. Principles of Health Care Administration. Dibagran Tehran, Tehran.

69. Mosadeghrad, A. M. and Tahery, H. 2004. Managers' Knowledge about Leadership Styles in Isfahan Medical University Hospitals. Isfahan, Iran, Grant.

70. Muchinsky, P. M. \& Iaffaldano, M. T. 1985. Job satisfaction and job performance: A meta-analysis. Psychological Bulletin, 97(2), 251 273.

71. Mugenda, O. M. \& Mugenda, A. G. 2003. Research methods: Qualitative and Quantitative Approaches. Nairobi: Acts Press.

72. O'Leary, Z. 2004. The essential guide to doing research. Sage Publications.

73. O'Reilly, C., Chatman, J., \& Caldwell, D. F. 1991. People and organizational culture: A profile comparison approach to assessing person-organization fit. Academy of Management Journal. 34, 487-516.

74. Oshagbemi, T. 1998. The impact of age on the job satisfaction of University teachers, Research in Education. 59(1), pp. 55 - 108.

75. Petty, M. M., McGee, G. W., \& Cavender, J. W. 1984. A meta-analysis of the relationship between individual job satisfaction and individual performance. Academy of Management Review. 9, 712 - 72 I.

76. Philippines : Addison- Wesley

77. Philippines : Addison- Wesley

78. Quarstein, V. A., McAfee R. B. and Glassman, M. 1992. The Situational Occurrences Theory of Job Satisfaction. Human Relations. 45(8), $859-$ 873.

79. Rowden, R.W. 2002. The Relationship between Workplace Learning and Job Satisfaction in U.S. Small To midsize businesses. Human Resource Development Quarterly, 13(4), 407- 425.

80. Saonee S., Munson, C. L., Suprateek, S. \& Suranjan C. 2009. Assessing the relative contribution of the facets of agility to distributed systems development success: an Analytic Hierarchy Process approach. European Journal of Information Systems. 18(4) pp 285 299.

81. Saunders, M., Lewis, P. and Thornhill, A. 2009. Research Methods for Business Students. Pearson, New York.

82. Seo, Y., Ko, J. and Price, J. L. 2004. The determinants of job satisfaction among hospital nurses: a model estimation in Korea. International Journal of Nursing Studies. 41, pp. 437-46.

83. Skansi, D. 2000. Relation of managerial efficiency and leadership styles - empirical study in Hrvatska elektroprivreda. Management. 5 (2), pp. 51-67.

84. Smith, P. C., Kendall, L. M., \& Hulin, C. L. 1969. The measurement of satisfaction in work and retirement. Chicago: Rand McNally.
85. Spector, P. E.1997. Job Satisfaction: Application, Assessment, Causes, and Consequences. California. Sage Publications, Inc.

86. Stewart, D. M. 1994. Handbook of Management Skills. 2nd ed., Gower Publishing Co., Aldershot.

87. Stordeur, S., Vandenberghe, C. and D'hoore, W. 2000. Leadership styles across hierarchical levels in nursing departments. Nursing Research. 49(1), pp. $37-43$

88. Toronto, Canada: Multi-Health Systems, Inc

89. Toronto, Canada: Multi-Health Systems, Inc.

90. Toronto, Canada: Multi-Health Systems, Inc.

91. Toronto, Canada: Multi-Health Systems, Inc.

92. Toronto, Canada: Multi-Health Systems, Inc.

93. Toronto, Canada: Multi-Health Systems, Inc.

94. Toronto, Canada: Multi-Health Systems, Inc.

95. Toronto, Canada: Multi-Health Systems, Inc.

96. Vance, C. and Larson, E. 2002. Leadership research in business and health care. Journal Nurse Scholash. 34(2), pp. 165 - 71.

97. Walliman, N. S. \& Walliman N. 2011. Research methods: the basics. Taylor and Francis Group.

98. Wanous, J. P., Reichers, A. E. \& Hudy, M. J. 1997. Overall Job Satisfaction: How Good Are Single Item Measure? Journal of Applied Psychology, the American Psychological Association, Inc. 82(2), 247 -252 .

99. Zeidner, M., \& Matthews, G. \& Roberts, R. D. 2004. Emotional Intelligence in the Workplace: A Critical Review. Applied Psychology $53,371-399$

\section{AUTHORS PROFILE}

I am Zairina Ibrahim, my current affiliation is with Information Technology and Innovation Centre, Management and Science University, University Drive Seksyen 13, Shah Alam 40100, Malaysia. my area of interest is Technology management

I am Md Gapar Md Johar, currently working with Information Technology and Innovation Centre, Management and Science University, University Drive Seksyen 13, Shah Alam 40100, Malaysia. My area of interest is Technology management.

I am Normy Rafida Abdul Rahman, and affiliated with Faculty Business Management and Professional Studies, Management and Science University, University Drive Seksyen 13, Shah Alam 40100, Malaysia. My area of interest is technology management. 